\title{
RANCANG BANGUN SISTEM INFORMASI PERKEBUNAN KELAPA SAWIT BERBASIS WEB UNTUK MENDUKUNG PELAPORAN HASIL KERJA (STUDI KASUS: PERKEBUNAN PALM NBH SEJAHTERA)
}

\author{
Yulianus Palopak dan Kurnia Rahmat \\ Fakultas Teknologi Informasi, Universitas Advent Indonesia
}

\begin{abstract}
Abstrak
Tujuan penelitian ini adalah untuk menganalisa dan merancang kebutuhan sistem informasi pada industri perkebunan khususnya perkebunan kelapa sawit sehingga dapat melakukan perencanaan, pelaksanaan dan pencatatan laporan kegiatan pekerjaan harian. Adapun metode yang digunakan dalam menyelesaikan penelitian ini adalah menggunakan metodologi SDLC (System Development Life Cycle), dengan menerapkan model Waterfall yang terdiri dari tahapan-tahapan: (1) Analisis; (2) Desain; (3) Implementasi; (4) Testing; (5) Pemeliharaan. Hasil dari penelitian ini berupa rancangan sistem informasi yang dapat digunakan pada perusahaan perkebunan kelapa sawit untuk membantu mengelola data dan pelaporan kegiatan berupa penyemprotan lahan, pembabatan, pemupukan dan pemanenan kelapa sawit. Diharapkan hasil rancangan ini dapat diimplementasikan secara langsung sehingga dapat diketahui efektifitas dan efisiensi dari sistem tersebut.
\end{abstract}

Kata-kata kunci: Sistem, informasi, sistem informasi, perancangan sistem, perkebunan.

\section{THE DESIGN OF WEB BASED INFORMATION SYSTEM OF PALM PLANTATION TO SUPPORT WORKING REPORT (CASE STUDY: NBH SEJAHTERA PALM PLANTATION)}

\begin{abstract}
The purpose of this study is to analyze and design the needs of information system in the plantation industry, especially for palm plantation to perform planning, execution and reporting of daily work activities. The methodology used in this research is SDLC (System Development Life Cycle), by applying Waterfall model that consist of stages such as: Analysis; Design; Implementation; Testing; and Maintenance. The result of this research is a design of information system that can be used in palm plantation company to help to manage data and reporting for their activities such as spraying, clearing, fertilizing and harvesting of palm. It is expected that the results of this design can be implemented directly in the real situation so that it can be known of the effectiveness and efficiency of the system.
\end{abstract}

\section{Latar Belakang Masalah}

Sektor pertanian dan perkebunan merupakan salah satu sektor yang cukup memiliki peran dalam sistem perekonomian Indonesia (Rosmiatia, Mustafid dan Widiyanto, 2015). Menurut Direktur Jenderal Perkebunan Indonesia, bahwa sektor perkebunan menyumbang devisa yang cukup besar dengan nilai ekspor sebesar 367,040 trilliun rupiah pada tahun 2014 (Dirjen Perkebunan, 2015). Salah satu sektor perkebunan yang cukup menguntungkan dan memberikan sumbangan besar bagi perekonomian Indonesia adalah perkebunan kelapa sawit. Menurut data Pusat Statistik Kelapa Sawit Indonesia bahwa pada tahun 2015 Indonesia merupakan produsen dan eksportir kelapa sawit terbesar di dunia dengan jumlah produksi sebesar 31,28 juta ton pada tahun 2015 dimana provinsi Riau merupakan penyumbang tertinggi sebesar 7,33 juta ton (Badan Pusat Statistik, 2015).

Seiring dengan berkembangya sektor perkebunan kelapa sawit ini maka berbagai kendala dihadapi untuk dapat bertahan, sehingga dibutuhkan pengelolaan yang baik. Pengelolaan perkebunan 
yang baik merupakan salah satu faktor keberhasilan terpenting untuk pengembangan berkelanjutan dan kelangsungan hidup perkebunan pada lingkungan yang cepat berubah saat ini (Husemann, dkk., 2012). Menurut Novkovic, dkk (2015) bahwa terdapat tiga faktor utama mengapa pengelolaan perkebunan sangat penting, antara lain lingkungan yang kompleks, struktur pertanian yang kompleks serta adanya pengenalan teknologi ke dunia perkebunan. Berkembanya kebutuhan pengelolaan perkebunan yang semakin baik membutuhkan sistem yang baik pula. Teknologi informasi merupakan sebuah pilihan yang tepat yang dapat diterapkan pada pengelolaan perkebunan kelapa sawit dimana manajemen pekebunan kelapa sawit saat ini semakin kompleks dibandingkan dengan beberapa dekade belakangan ini (Zulafwan, 2016).

Salah satu Perusahaan perkebunan kelapa sawit yang berlokasi di Tanjung Medan, Riau yang dikelolah oleh PT. Palm Nbh Sejahtera, memulai usahanya dari awal dengan membeli lahan kosong dan menanami lahan dengan kelapa sawit. Luasnya area perkebunan serta letak perkebunan yang berjauhan satu sama lain serta berjauhan dengan kantor pusat menyebabkan kesulitan dalam melakukan kontrol terhadap berbagai kegiatan harian seperti penyemprotan, pembabatan lahan, pemupukan hingga kegiatan panen. Perusahaan serta pekerja menerapkan sistem informasi yang terintegrasi untuk melakukan pengumpulan, pengolahan, pemanfaatan serta penyediaan akan data-data hasil kegiatan harian (Novkovic, dkk., 2015).

Tujuan dari penelitian ini adalah merancang sebuah sistem informasi berbasis web yang dapat memudahkan para pegawai pada perusahaan perkebunan kelapa sawit dalam merencanakan dan mengontrol serta melaporkan kegiatan harian khususnya kegiatan yang dilakukan di area perkebunan kelapa sawit.

\section{Landasan Teori \\ Data dan Informasi}

Ada banyak diskusi dan pendapat mengenai data, informasi beserta hubungannya. Menurut Rowley (2007) bahwa data didefinisikan sebagai simbol yang mewakili sifat benda, kejadian dan lingkungannya. Data merupakan produk yang belum memiliki manfaat sebelum dibentuk menjadi sesuatu yang dapat digunakan. Sementara informasi terkandung dalam deskripsi, jawaban atas pertanyaan yang dimulai dengan kata-kata seperti siapa, apa, kapan dan berapa banyak. Sistem informasi menghasilkan, menyimpan, mengambil dan memproses data. Informasi disimpulkan dari data. Sedangkan menurut Liew (2013), data merupakan simbol-simbol serta sinyal yang dapat disimpan dan dibaca, dimana simbol-simbol tersebut dapat berupa kata, teks, angka, diagram dan gambar sedangkan sinyal dapat berupa sensor, suara, bau dan rasa. Menurut Liew (2013), informasi merupakan pesan yang mempunyai arti yang relevan atau input dari keputusan dan tindakan. Sedangkan menurut Boell dan Kecmanovic (2015), bahwa informasi muncul pada penjelasan, jawaban terhadap pertanyaan-pertanyaan yang dimulai dengan siapa, mengapa, dimana, kapan dan berapa banyak).

\section{Sistem}

Menurut Whitten (2007) bahwa sistem dapat diartikan sebagai sekumpulan komponen yang saling berhubungan yang berfungsi bersama-sama untuk mencapai hasil yang diinginkan. Sedangkan menurut McLeod (2007) bahwa sistem merupakan elemen-elemen yang terintegrasi yang memiliki tujuan yang sama.

\section{Sistem Informasi}

Menurut Whitten (2007) bahwa sistem informasi adalah pengaturan akan orang, data, proses dan teknologi informasi yang berinteraksi satu sama lain untuk mengumpulkan, memproses, menyimpan dan menyediakan informasi yang dibutuhkan oleh sebuah organisasi. Sistem informasi merupakan sistem yang memproses informasi dengan cara menangkap, mentransmisikan, menyimpan, mengambil, memanipulasi dan menampilkannya (Alter, S, 2008). Sistem informasi melibatkan berbagai variasi teknologi informasi seperti komputer, perangkat lunak, basis data, sistem komunikasi, internet dan banyak lagi yang melakukan tugas-tugas tertentu serta berinteraksi dengan berbagai pelaku dalam 
organisasi Selanjutnya Sistem informasi mengumpulkan menyimpan, mengambil dan memproses data yang biasanya riproses secara statistik dan arithmatik. (Boell and Kecmanovic, 2015).

\section{Analisa Sistem}

Selama ini sistem yang berjalan dalam perusahaan ini masih menggunakan sistem laporan manual yang sangat sederhana dan belum menggunakan sistem komputerisasi. Semua alur pecatatan masih dilakukan oleh asisten dan mandor secara manual kemudian diserahkan kepada administrator untuk dilakukan pencatatan kembali kedalam buku tersendiri. Pada perancangan sistem informasi ini diperlukan fungsi-fungsi sebagai berikut:

1. Fungsi catatan hasil kerja Penyemprotan serta barang yang dibutuhkan

2. Fungsi catatan kerja Babatan beserta barang yang dibutuhkan

3. Fungsi catatan hasil kerja Pemupukan beserta dengan barang yang di butuhkan

4. Fungsi pencatatan hasil Panen lahan produksi

5. Fungsi laporan barang dan hasil kerja lapangan

6. Fungsi Pencatan inventory bahan dan peralatan

7. Fungsi laporan Gaji/Upah

\section{Perancangan Sistem}

Dalam perancangan sistem ini digunakan UML sebagai alat bantu menjelaskan model kebutuhan fungsional sistem yang dilakukan dengan menggunakan diagram use case dan diagram aktifitas. Diagram use case menjelaskan bagaimana hubungan dan peran yang terjadi antara aktor-aktor yang terlibat pada sistem, terdiri dari aktor, use case, dan hubungan antara use case dengan aktor. Sedangkan diagram Aktifitas merupakan sebuah teknik untuk menggambarkan logika prosedural dan alur kerja yang memungkinkan setiap pengguna dalam melakukan aktifitas terhadap sistem (Zulafwan, 2016).

Pada gambar 1 ditampilkan diagram use case sistem yang terdiri atas tiga aktor yaitu Admin, Asisten dan Mandor. Pada diagram tersebut juga terdapat usecase login, penyemprotan, pembabatan, pemupukan, pemanenenan, pelaporan dan logout. 


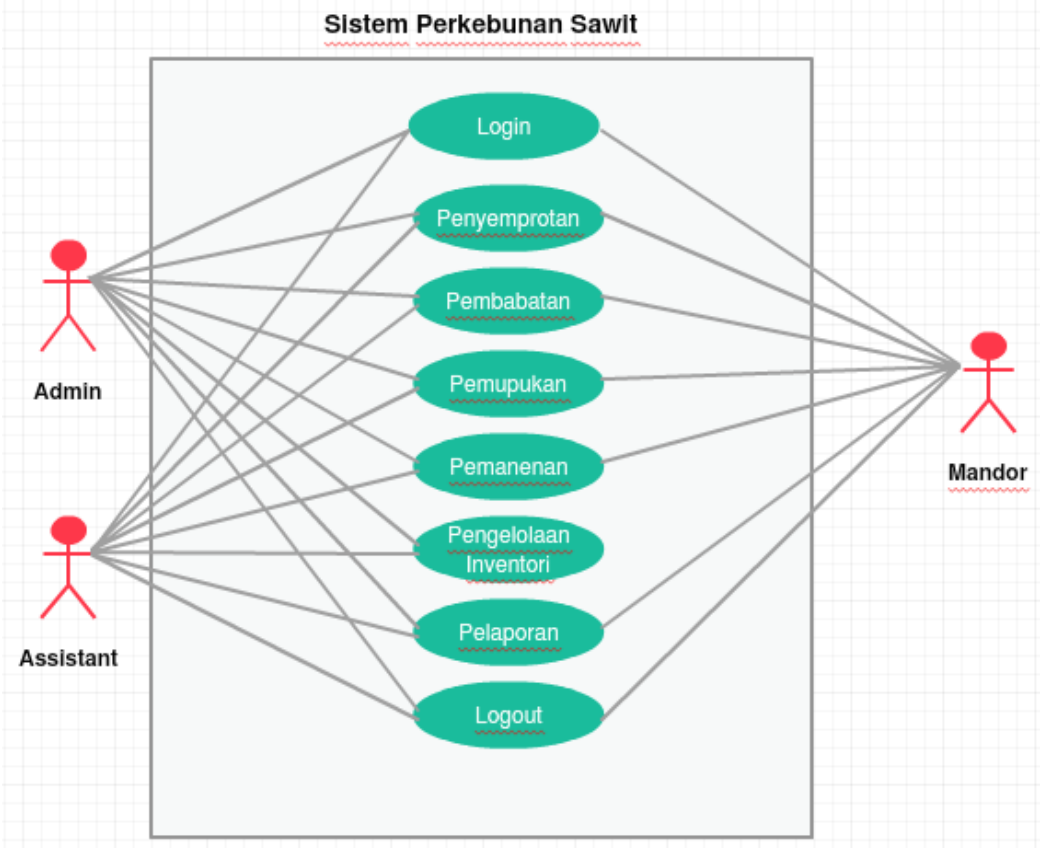

Gambar 1 Diagram Use Case

Selanjutnya dilakukan pemodelan aktifitas-aktifitas sistem yang menunjukkan alur kerja sistem secara berurutan. Pada gambar 2 berikut menampilkan aktifitas semperotan dimana asisten dapat melakukan inputan proses hasil kerja penyemprotan serta banyaknya racun yang digunakan.

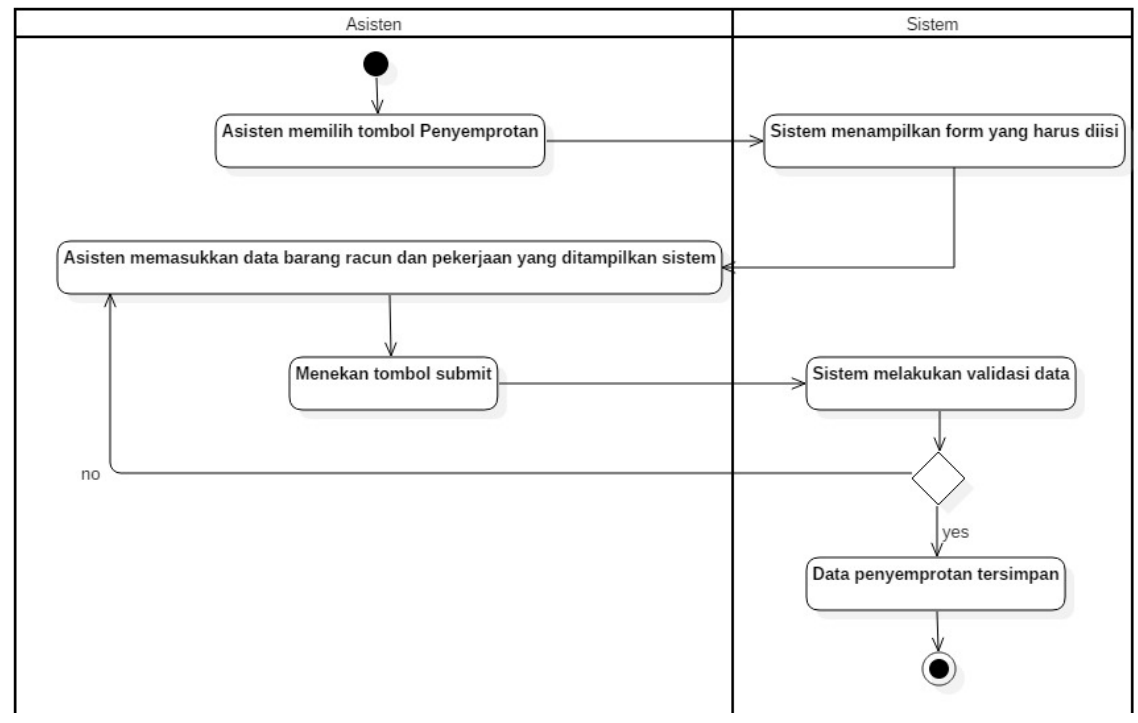

Gambar 2 Activity Diagram Pencatatan Penyemprotan

Aktifitas Pembabatan dapat dilihat pada gambar 3 berikut ini adalah dimana asisten dapat melakukan inputan proses hasil kerja babatan lahan serta banyaknya bahan dan peralatan yang digunakan. 


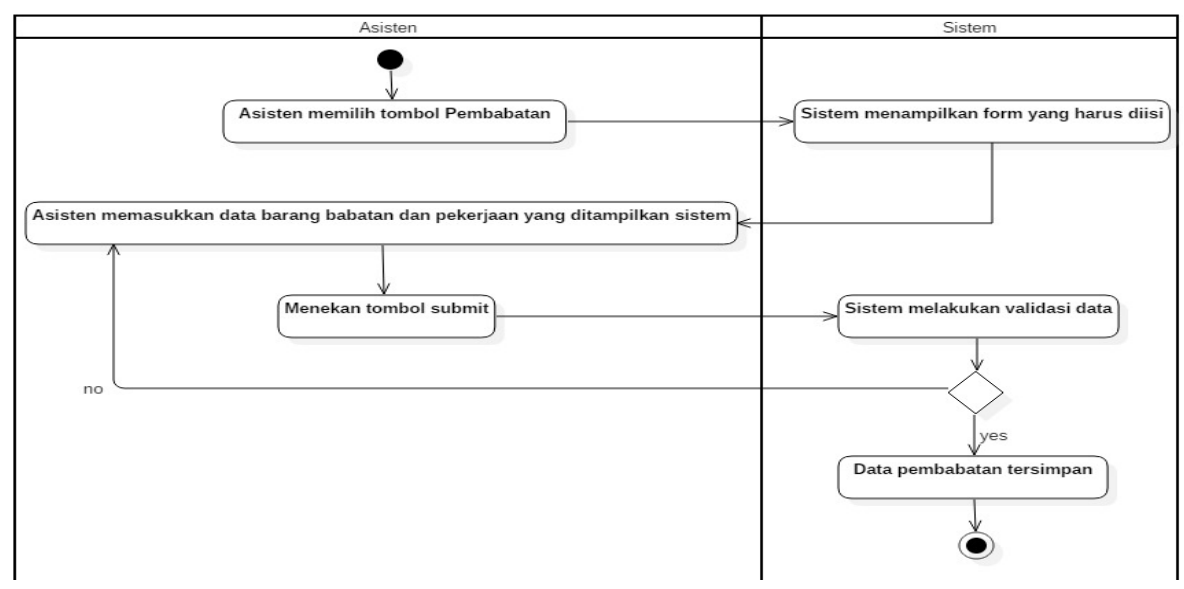

Gambar 3 Activity Diagram Aktifitas Pembabatan

Aktifitas Pemupukan dilakukan oleh asisten dengan menginput hasil kerja pemupukan kelapa sawit di lahan serta banyaknya pupuk yang digunakan. Sistem menampilkan sebuah form yang harus diisi oleh asisten berdasarkan hasil kerja semprot yang ada dilapangan, seperti yang terlihat pada gambar 4 berikut.

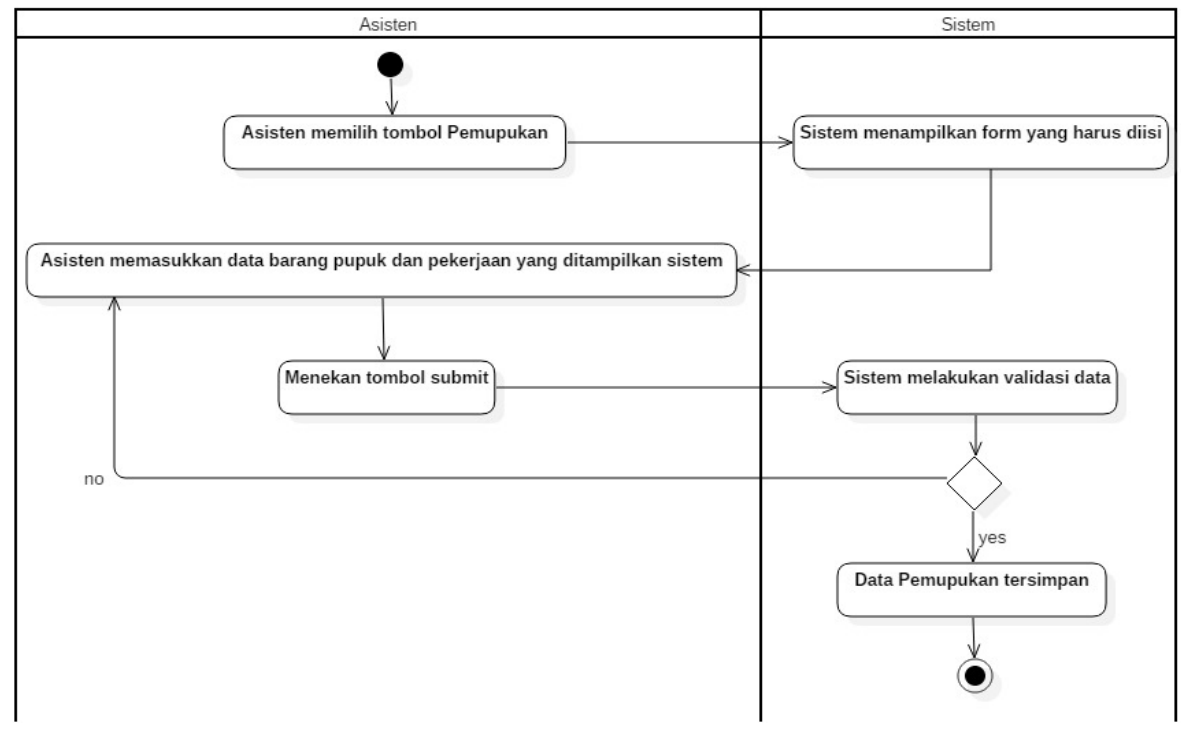

Gambar 4 Activity Diagram Aktifitas Pemupukan

Pada gambar 5 ditampilkan aktifitas diagram panenan dimana asisten dapat melakukan inputan proses hasil kerja panenan sawit yang terjadi di lahan serta banyaknya hasil panen dalam tonasi (total berat) dan Tros (jumlah janjangan sawit) yang didapatkan dari seluas lahan yang produksi. 


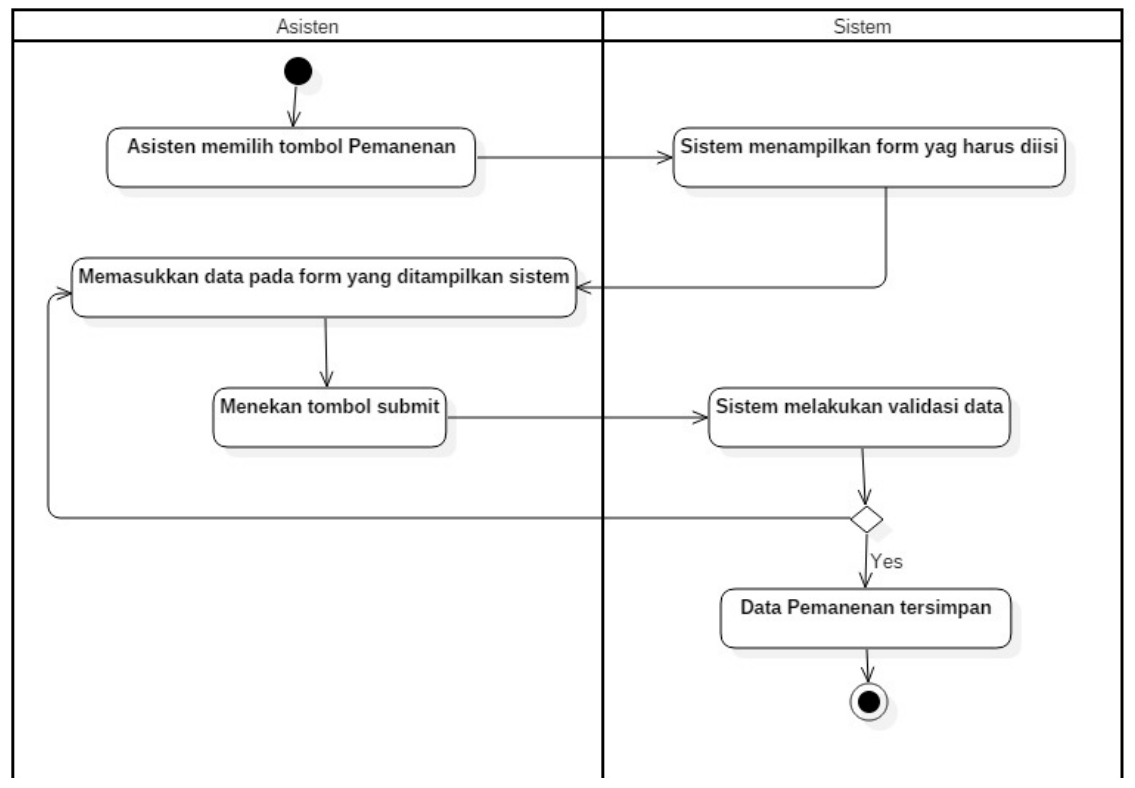

Gambar 5 Activity Diagram Aktifitas Pemanenan

Pada aktifitas laporan ini asisten dapat membuat sebuah laporan hasil pekerjaan serta barang yang digunakan mendukung pekerjaan. Berikut ini adalah prosedur laporan yang dapat dilihat pada gambar 6 berikut ini.

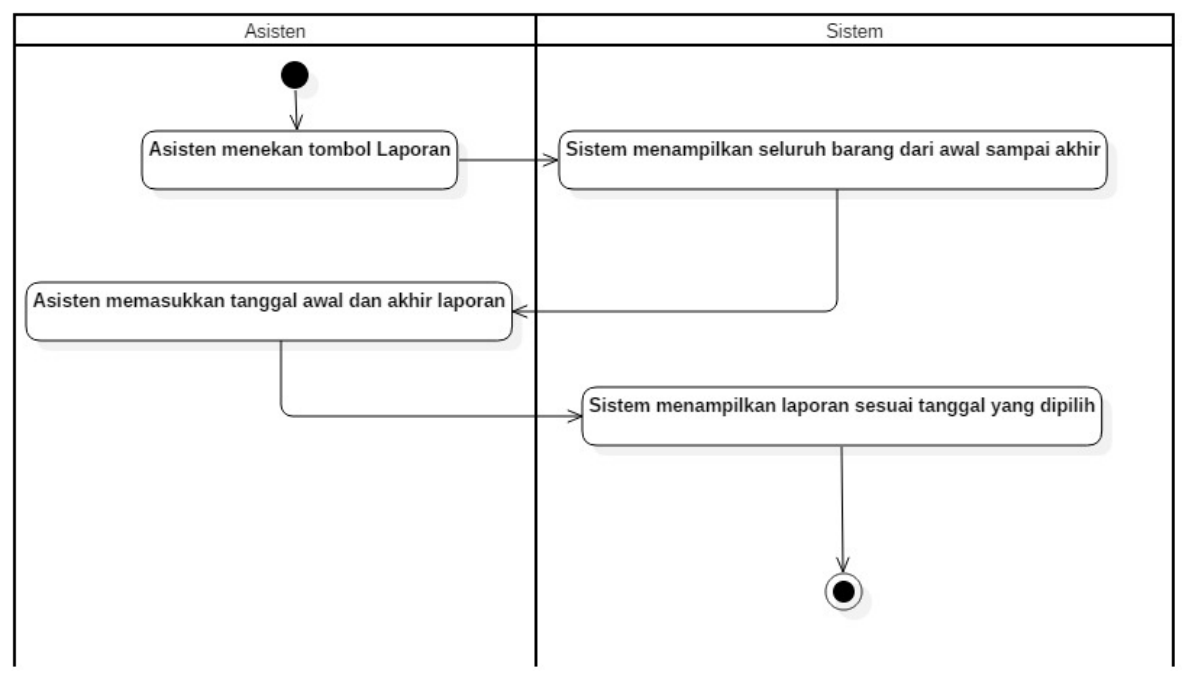

Gambar 6 Activity Diagram Laporan

\section{Hasil dan Pembahasan}

Untuk dapat mengkases kedalam sistem, maka terlebih dahulu semua user melakukan login dengan memasukkan username dan password secara benar dan sistem akan menampilkan halam home sebagai tampilan utama. Pada halaman utama menu-menu yang dapat dipilih sesuai fungsinya, seperti gambar 7 berikut. Pada menu ini juga terdapat menu pegawai sebagai menu tambahan untuk menginput dan mengelola data pegawai. Terdapat juga menu lokasi untuk mengelola lokasi perkebunan yang ada. 


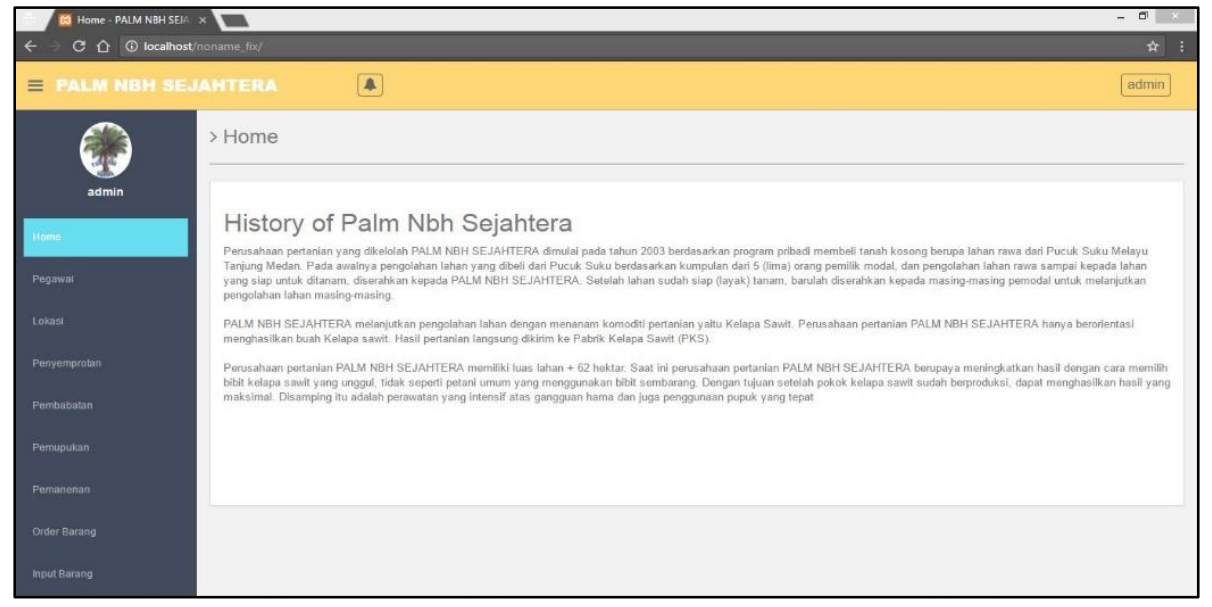

Gambar 7 Tampilan Halaman Utama

Pada menu utama juga terdapat menu penyemprotan, seperti yang terlihat pada gambar 8 . Menu penyemprotan ini digunakan untuk menginput dan mengelola data pekerjaan penyemprotan yang biasa dilakukan. Pekerjaan penyemprotan biasanya dilakukan untuk menyemprot tanaman supaya bebas dari hama serta juga pernyemprotan terhadap tumbuhan-tumbuhan liar. Pekerjaan ini dilakukan oleh karyawan pada lokasi tertentu di area perkebunan dengan menggunakan racun atau pestisida. Pada menu ini juga terdapat informasi tentang kegiatan penyemprotan yang sudah dilakukan sebelumnya.

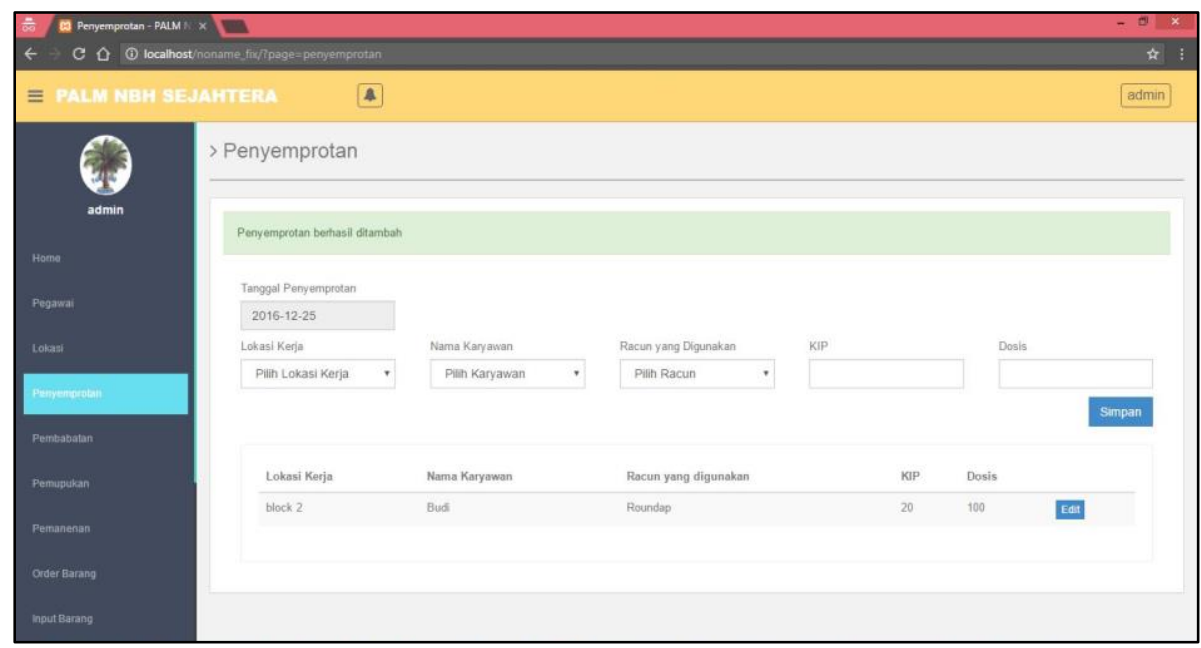

Gambar 8 Tampilan Penyemprotan

Setelah rumput liar disemprot, maka selanjutnya dilakukan proses pembabatan untuk membersihkan area perkebunan dari rumput liar serta membersihkan tangkai-tangkai pohon kelapa sawit. Untuk menginput dan mengelola data pekerjaan pembabatan maka dapat dilakukan melalui menu pembabatan seprti pada gambar 9 berikut. Menu ini berisikan data dan informasi yang berhubungan dengan data kegiatan pekerjaan pembabatan yang sudah dilakukan sebelumnya. 


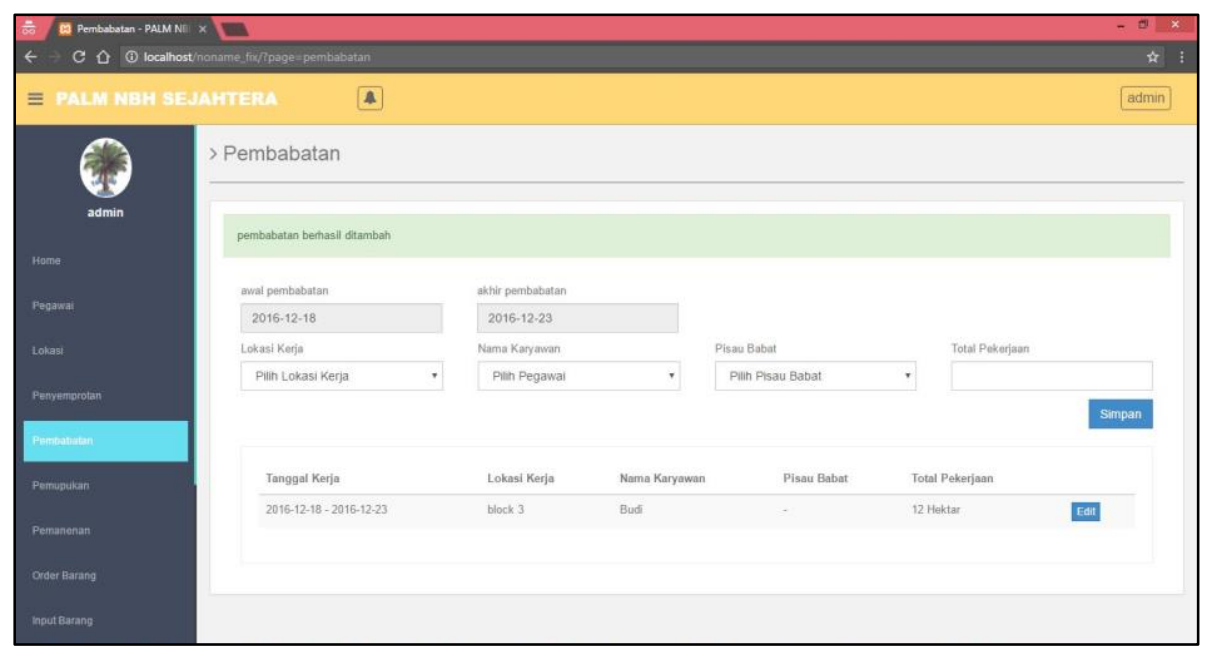

Gambar 9 Tampilan Pembabatan

Setelah pekerjaan pembabatan dan pembersihan dilakukan, maka selanjutnya dilakukan pekerjaan pemupukan terhadap pohon kelapa sawit. Kegiatan ini melibatkan penggunaan jenis pupuk tertentu serta sejumlah dosis pupuk untuk setiap area. Pada gambar 10 berikut menampilkan form yang harus diisi dengan data kegiatan pemupukan. Pada tampilan ini juga terdapat informasi tentang data pemupukan yang sudah dilakukan sebelumnya.

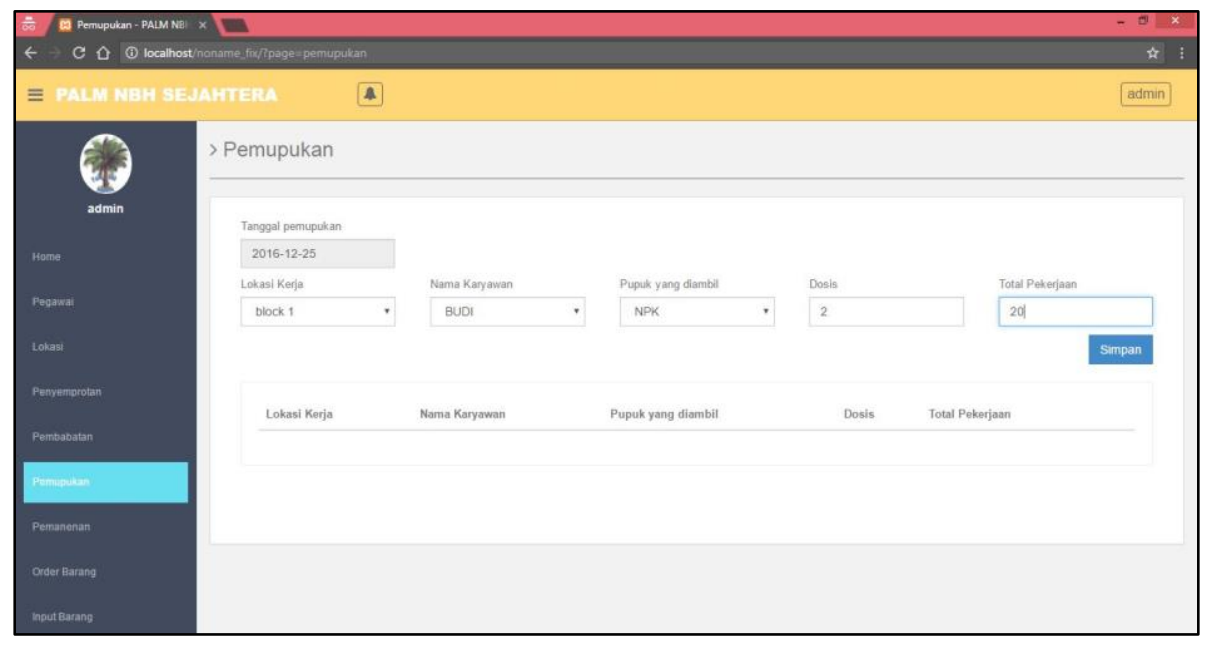

Gambar 10 Tampilan Pemupukan

Untuk melihat pekerjaan pemanenan yang terjadi maka dapat diakses melalui menu pemanenan seperti pada gambar 11 berikut. Menu pemanenan ini berisikan form yang digunakan untuk mengisi data panen serta seluruh informasi yang berhubungan dengan kegiatan pemanenan kelapa sawit. 


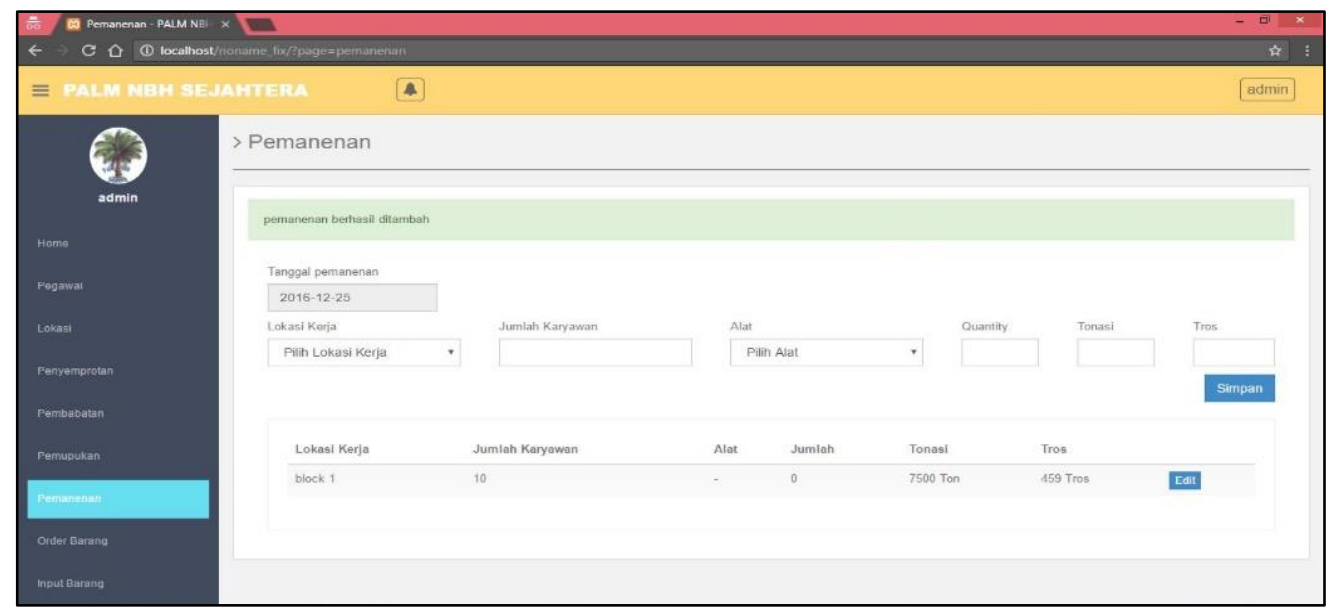

Gambar 11 Tampilan Pemanenan

Setelah semua data diinput ke sistem, maka dapat dibuat laporan untuk dapat melihat seluruh data yang sudah dinput berupa data laporan penyemprotan, laporan pembabatan, laporan pemupukan serta laporan pemanenan. Untuk melihat hasil pekerjaan penyemprotan maka dapat dilihat pada menu laporan kerja dengan submenu penyemprotan seperti terlihat pada gambar 12 berikut. Menu laporan penyemprotan ini menampilkan laporan seluruh hasil pekerjaan penyemprotan yang dapat dilakukan dalam kurun waktu tertentu.

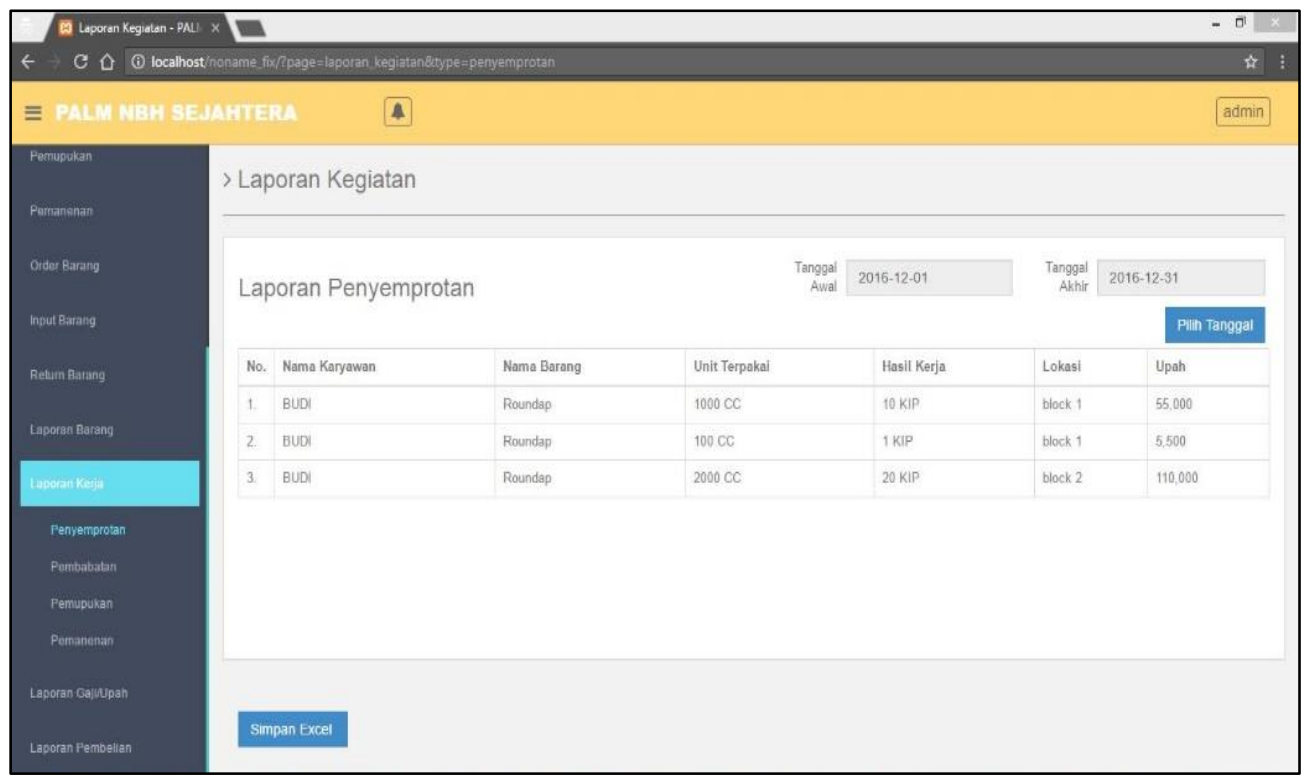

Gambar 12 Tampilan Laporan Kerja Penyemprotan

Untuk melihat hasil pekerjaan pembabatan maka dapat dilihat pada menu laporan kerja dengan submenu pembabatan seperti terlihat pada gambar 13 berikut. Menu laporan pembabatan ini menampilkan laporan seluruh hasil pekerjaan pembabatan dimana data dapat ditampilkan untuk kurun waktu tertentu yang diinginkan. 


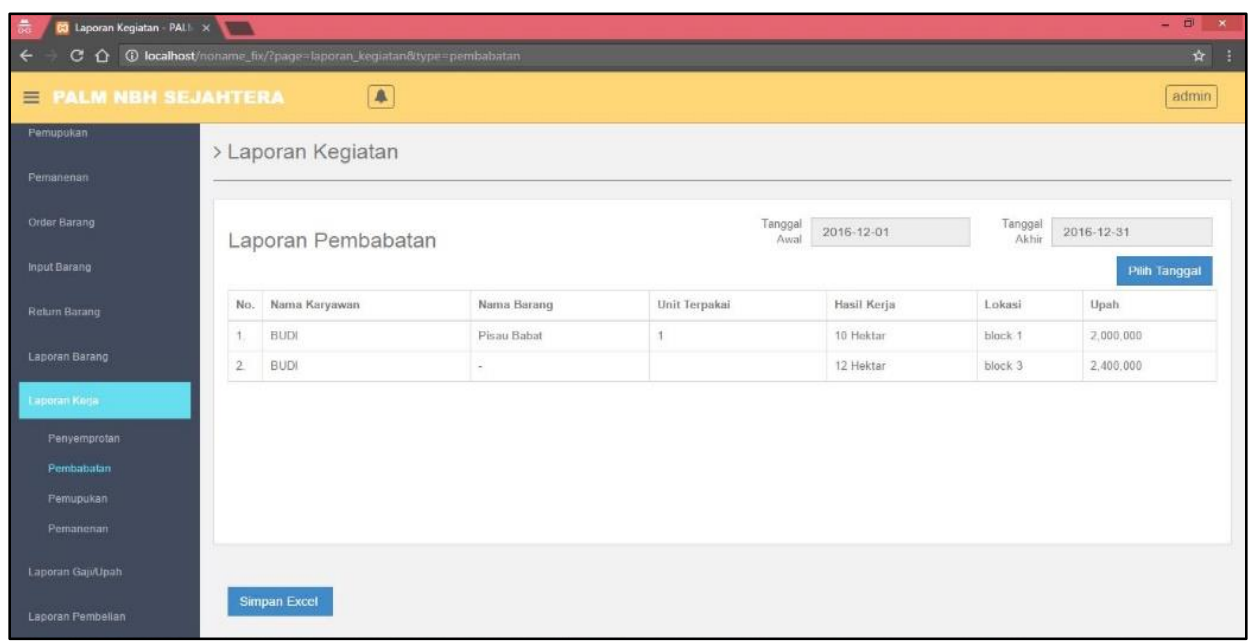

Gambar 13 Tampilan Laporan Kerja Pembabatan

Demikian halnya untuk data hasil pemanenan dapat dilihat pada menu laporan kerja pemanenan sebagaimana dapat dilihat pada gambar 14 berikut. Pada menu ini berisi data hasil pemanenan yang sudah dilakukan. Data pemanenan tersebut berisi data karyawan yang mengerjakan, peralatan yang digunakan, hasil per lokasi serta upah pekerja pemanen. Untuk memudahkan dalam penyampaian laporan maka semua data laporan dapat diekspor ke dalam format Ms.Excel.

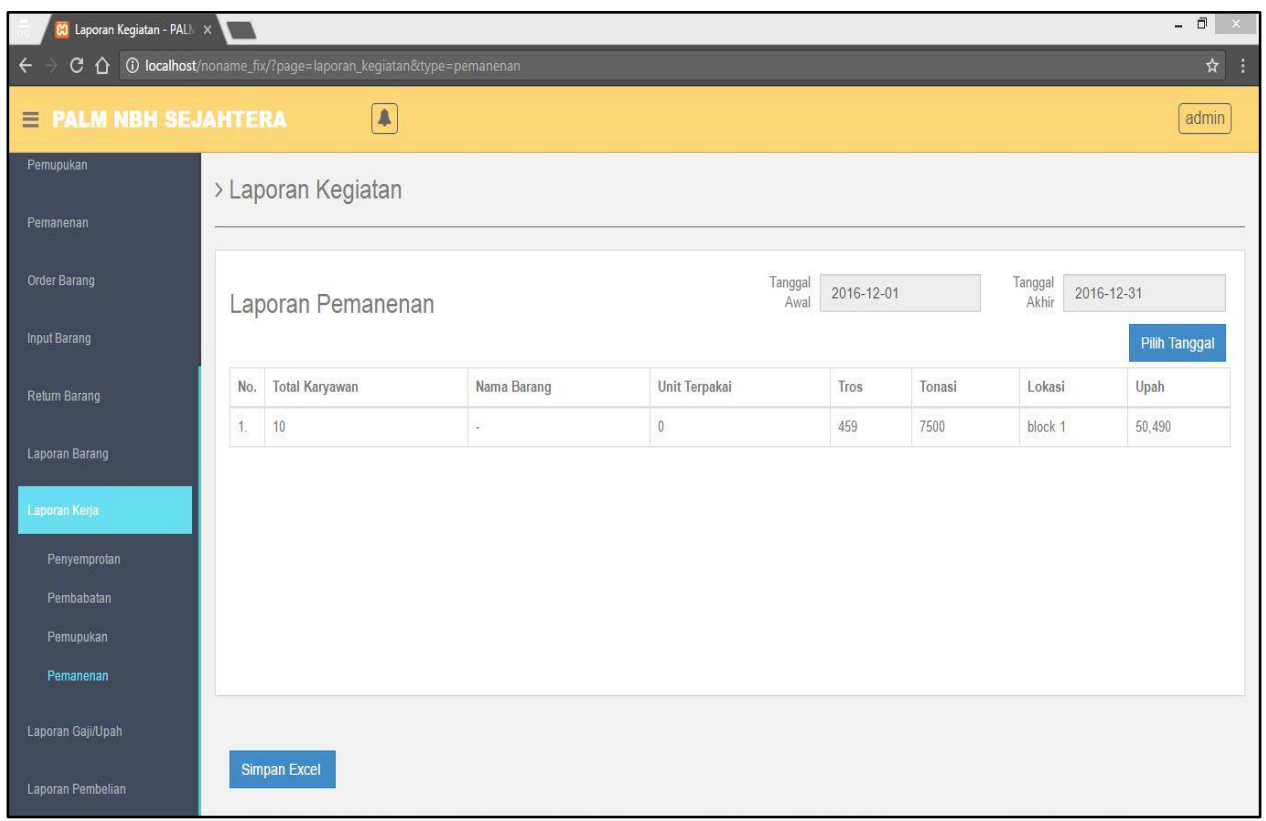

Gambar 14 Tampilan Laporan Kerja Pemanenan

Untuk selanjutnya dari sistem juga dapat dikelola laporan penggajian para pekerja yang dihitung berdasarkan hasil kerja mereka. Untuk mengelola laporan penggajian dapat dilakukan pada menu Laporan Gaji seperti terlihat pada gambar 15 berikut: 


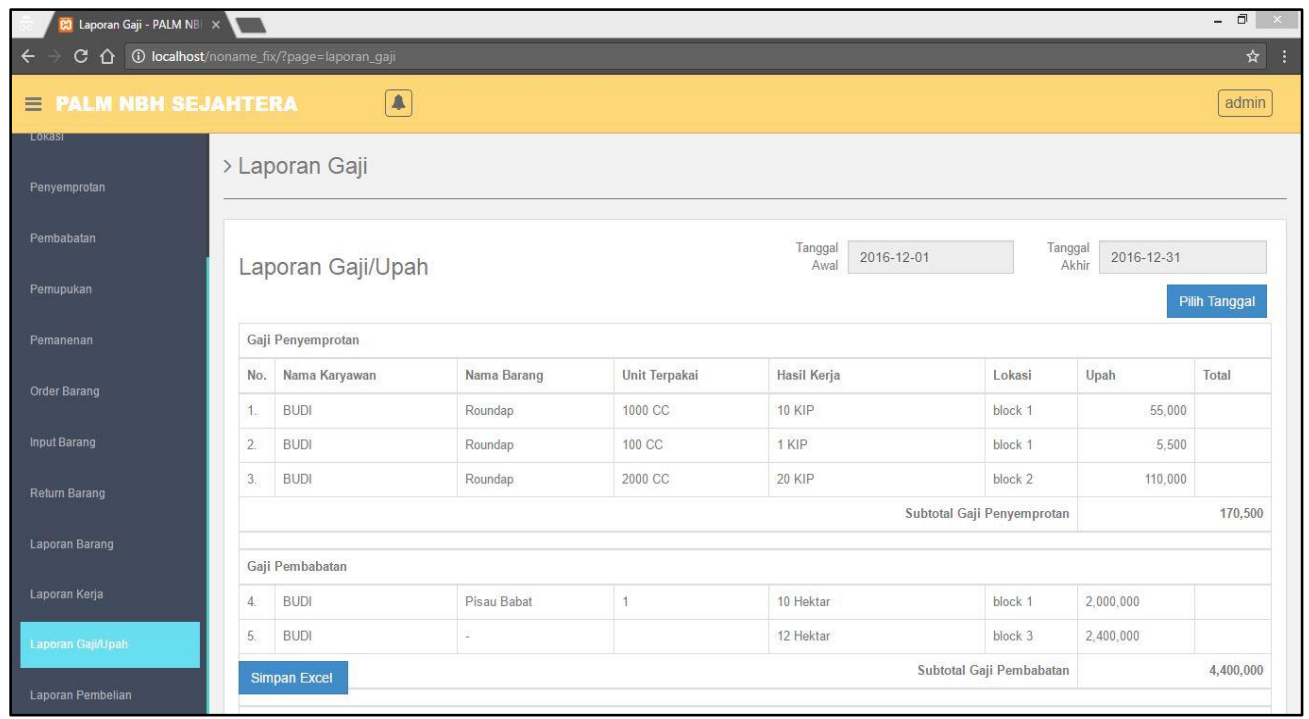

Gambar 15 Tampilan Laporan Gaji/Upah

\section{Kesimpulan dan Saran}

Hasil dari penelitian ini adalah rancangan sistem informasi perkebunan kelapa sawit yang dapat digunakan untuk mengelola data hasil pekerjaan berupa pembabatan, penyemprotan, pemupukan dan pemanenan serta data inventori bahan dan peralatan pada perusahaan Palm Nbh Sejahtera. Rancangan sistem informasi ini masih terbatas pada beberapa aktifitas utama, sehingga diharapkan rancangan ini dapat diperluas pada seluruh aktifitas yang ada pada perkebunan kelapa sawit. Rancangan sistem informasi ini juga diharapkan dapat dikembangkan pada platform yang lain seperti platform Android sehingga lebih memudahkan untuk mengakses sistem yang ada.

\section{Referensi}

1. Alter, S. 2008. "Defining Information Systems as Work Systems: Implications for the IS Field". European Journal of Information Systems 17, 5 (2008), 448-469.

2. Anthony Liew. 2013. "DIKIW: Data, Information, Knowledge, Intelligence, Wisdom and their Interrelationships". Business Management Dynamics Vol.2, No.10, Apr 2013, pp.49-62.

3. Badan Pusat Statistik. 2015. "Statistik Kelapa Sawit Indonesia 2015". Badan Pusat Statistik, 2015. ISSN/ISSN Number: 1978-9947

4. Boell, K.S., dan Kecmanovic, D.C. 2015. "What is an Information System?". 48th Hawaii International Conference on System Sciences, 2015

5. Boell, K.S., dan Kecmanovic, D.C. 2015. "What is 'Information' Beyond a Definition?". Thirty Sixth International Conference on Information Systems, Fort Worth 2015

6. Dirjen Perkebunan. 2015. "Statistik Perkebunan Indonesia 2014-2016". Direktorat Jenderal Perkebunan, Desember 2015.

7. Husemann Christoph, Novković Nebojsa and Vukelić Natasa. 2012. "The Model Of Farm Management Information System: A Case-Study Of Diversified German Farm". Deturope-The Central European Journal Of Regional Development And Tourism Vol.4 Issue 1 2012. ISSN 18212506

8. Novkovic Nebojsa, Huseman Christoph, Zoranovic Tihomir dan Mutavdzic Beba. 2015. "Farm Management Information Systems". Proceedings of the 7th International Conference on Information and Communication Technologies in Agriculture, Food and Environment (HAICTA 2015), Kavala, Greece, 17-20 September 2015. 
9. Rosmiatia, Mustafid dan Ibnu Widiyanto. 2015. "Sistem Informasi Pengukuran Kinerja Pada Perkebunan Kelapa Sawit Dengan Menggunakan Metode Balanced Scorecard". Jurnal Sistem Informasi Bisnis 01 (2015) On-line : http://ejournal.undip.ac.id/index.php/jsinbis

10. Rowley Jennifer. 2007. The Wisdom Hirarchy: "Representations of The DIKW Hierarchy." Journal of Information Science, 33 (2) 2007pp. 163-180.

11. Whitten, J.L \& Bentley, L.D. 2007. "Systems Analysis and Design Methods 7ed". The McGraw Hill Companies, Inc. New York. 2007

12. Zulafwan. 2016. "Sistem Informasi Geografis Pemetaan Perkebunan Sawit Berbasis Web". Riau Journal Of Computer Science Vol.2 No.2 Tahun 2016 : 7 - 16. ISSN : 2477-6890 